\title{
Morphological and behavioural changes occur following the X-ray irradiation of the adult mouse olfactory neuroepithelium
}

\author{
Carla Cunha, Yvonne Hort, John Shine and Kharen L Doyle*
}

\begin{abstract}
Background: The olfactory neuroepithelium lines the upper nasal cavity and is in direct contact with the external environment and the olfactory bulbs. The ability to self-renew throughout life and the reproducible recovery after injury, make it a model tissue to study mechanisms underlying neurogenesis. In this study, X-rays were used to disrupt proliferating olfactory stem cell populations and to assess their role in the cellular and morphological changes involved in olfactory neurogenic processes.

Results: We have analysed the histological and functional effects of a sub-lethal dose of X-rays on the adult mouse olfactory neuroepithelium at 2 hours, 24 hours, 1 week, 2 weeks and 5 weeks. We have shown an immediate cessation of proliferating olfactory stem cells as shown by BrdU, Ki67 and pH3 expression. At 24 hours there was an increase in the neural transcription factors Mash1 and Pax6 expression, and a disruption of the basal lamina and increase in glandular cell marker expression at 1 week post-irradiation. Coincident with these changes was an impairment of the olfactory function in vivo.
\end{abstract}

Conclusions: We have shown significant changes in basal cell proliferation as well as morphological changes in the olfactory neuroepithelium following X-ray irradiation. There is involvement of the basal lamina as well as a clear role for glandular and sustentacular cells.

Keywords: Olfactory neuroepithelium, X-ray irradiation, Proliferation, Apoptosis, Adult stem cells

\section{Background}

The olfactory neuroepithelium $(\mathrm{ON})$ is a specialized epithelium responsible for the perception of odours and undergoes neurogenesis throughout life in order to cope with damage suffered by being in direct contact with the external environment. It is also an easily accessible source of stem cells for cell therapy, so that the ON has become a useful model of neurogenesis [1,2].

The ON is a simple pseudostratified epithelium composed, in a basal to apical organization, of horizontal basal cells, globose basal cells, olfactory sensory neurons (OSN), Bowman's gland duct cells, microvillar cells and sustentacular cells. Underlining the ON, the lamina propria is composed of connective tissue, OSN axon bundles and respective olfactory ensheathing glia, blood

\footnotetext{
* Correspondence: k.doyle@garvan.org.au

Neuroscience Research Program, Garvan Institute of Medical Research, Sydney, Australia
}

\section{Biomed Central

(c) 2012 Cunha et al.; licensee BioMed Central Ltd. This is an Open Access article distributed under the terms of the Creative Commons Attribution License (http://creativecommons.org/licenses/by/2.0), which permits unrestricted use, distribution, and reproduction in any medium, provided the original work is properly cited. vessels and Bowman's glands [3,4]. Many studies have involved the identification of the ON stem cell and both horizontal basal cells and globose basal cells have been identified as two distinct putative stem cell populations, responsible for giving rise to all the different cell types within the $\mathrm{ON}$ and having different roles in normal neurogenesis and neuronal replacement after injury [1,5-9]. In previous studies sustentacular cell endfeet showed expression of the neural stem cell marker, nestin [10] and were likened to radial glial cells. Isolated populations of glandular cells were able to proliferate and form olfactory neurospheres [11]. This suggests that there are other potential populations of olfactory stem cells within the mouse ON.

Different models of ON degeneration have been used, including the exposure to the solvents zinc sulphate $[12,13]$, acetone [14], toluene [15] and the anti-thyroid drug, methimazole $[16,17]$. Another approach has been the inhalation of volatile chemicals, such as $\mathrm{CO}_{2}$ [18] 
and methyl bromide [19,20]. All of these methods rely on a widespread variable degeneration of the $\mathrm{ON}$, destroying multiple cell populations, without specifically targeting olfactory stem cells. Bulbectomy instead induces a retrograde degeneration of OSNs but does not allow for axonal re-targeting to the olfactory bulb [21,22].

In this study, we analysed the effects on neuronal and non-neuronal cells within the $\mathrm{ON}$ following X-ray irradiation of proliferating olfactory stem cells. Neural stem cells are more vulnerable than other cell types to ionizing radiation. It has been shown that ionizing radiation induces apoptosis of proliferating stem cells in the dentate gyrus of the adult rat hippocampus [23]. X-ray irradiation of young adult rat brain has resulted in apoptosis especially in the subependyma, a region harbouring a population of proliferating neural and glial stem cells [24-26]. Moreover, it has been demonstrated that X-ray irradiation can specifically target the neural stem cell population in the rat brain subventricular zone [27].

We hypothesize, based upon previous work published by our group, that glandular cells, apically-situated sustentacular cells as well as suspected basal cells will be affected by X-ray irradiation and cause both morphological and behavioural disruption of the mouse ON. This study contributes to the understanding of cellular events that occur within several olfactory cell populations after an induced selective damage to the proliferating olfactory stem cell populations.

\section{Results}

Anaesthetized adult mice were irradiated with a sublethal dose of X-rays on the mouse ON. The olfactory bulbs (OB) were protected from irradiation by use of a lead shield designed to protect the whole body except the nose snout (Figure 1A). Experimental groups were as follows: unlesioned control group, 2 hours, 24 hours, 1 week, 2 weeks and 5 weeks post-X-ray irradiation groups, with all animals injected with BrdU 2 hours before perfusion. Mice were monitored and weighed daily. None of the irradiated mice presented with oral or nasal ulceration, nasal discharge, breathing problems, nose scratching or signs of distress at any level. Olfactory behavioural tests were performed as well as ON detailed immunohistochemical analysis. Due to the complexity and timing of the olfactory behavioural tests, these were not performed for the 2 hours group.

\section{Morphology of the ON and OB post-irradiation}

Haematoxylin and eosin ( $\mathrm{H} \& \mathrm{E})$ staining was performed on both ON (including the vomeronasal organ) and OB and sections analyzed at roughly the same coronal level for each group. For the ON, 5 areas (4 within the turbinates and 1 within the nasal septum) were defined for morphological analysis and for posterior detailed immunohistochemical analysis (Figure 1B). The gross morphology of the turbinates and nasal septum as discerned using low magnification microscopy was identical for all groups indicating that following irradiation no gross abnormalities occurred within the mouse ON (Figure 1B,C) or vomeronasal organ (results not shown).

We analysed the morphology of the $\mathrm{ON}, \mathrm{OB}$ as well as the nerve fibres connecting them. We studied these structures following staining of $\beta$ IIITubulin. We showed that in the controls and at all time points following irradiation (only 24 hour and 5 week post-irradiation in figure) BIIITubulin was present in the cell soma of OSNs, processes and axon bundles in the $\mathrm{ON}$ (Figure 2B,D,F). Furthermore, at low magnification the
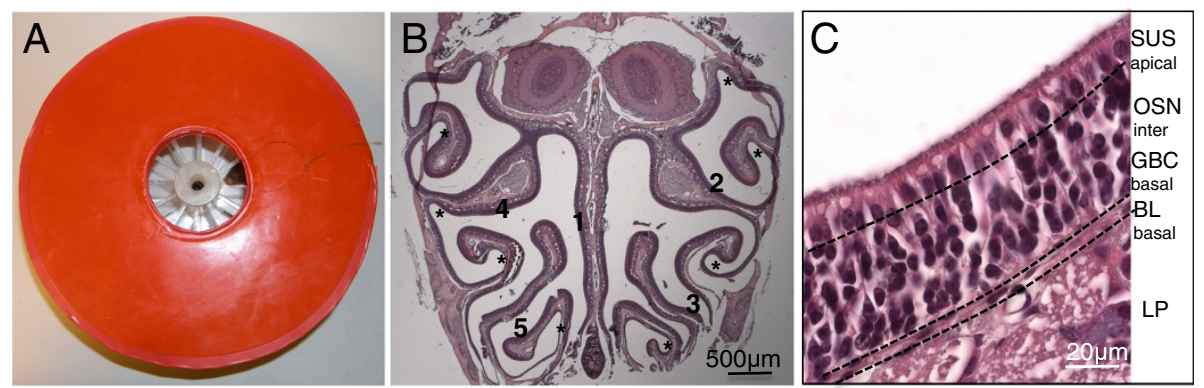

Figure $1 \mathrm{X}$-ray irradiation of mice and morphological analysis. A, X-ray irradiation was performed on anaesthetized adult mice placed in a circular Perspex pie chamber, covered with a lead shield (red) to protect the whole body except the nose snout. The OB were protected from irradiation, leaving the ON exposed. B,C, Photomicrographs showed the anatomy of the mouse ON stained with H\&E. B, Coronal section/ anteroposterior section of the ON showing the approximate location of the 5 areas analyzed for all immunohistochemical analysis, corresponding to the middle of the nasal septum (1), one more superior and one more inferior area of both the left $(2,3)$ and right $(4,5)$ turbinates. $\mathbf{C}$, Higher magnification of the $\mathrm{ON}$ at the level of the turbinates, showing the basal lamina (BL) in the basal layer, the sustentacular cell nuclei layer (SUS) in the apical layer, the olfactory sensory neurons (OSN) in the intermediate layer and globose basal cells (GBC) also in the basal layer, and the underlying lamina propria (LP). * Bowl-like areas. 

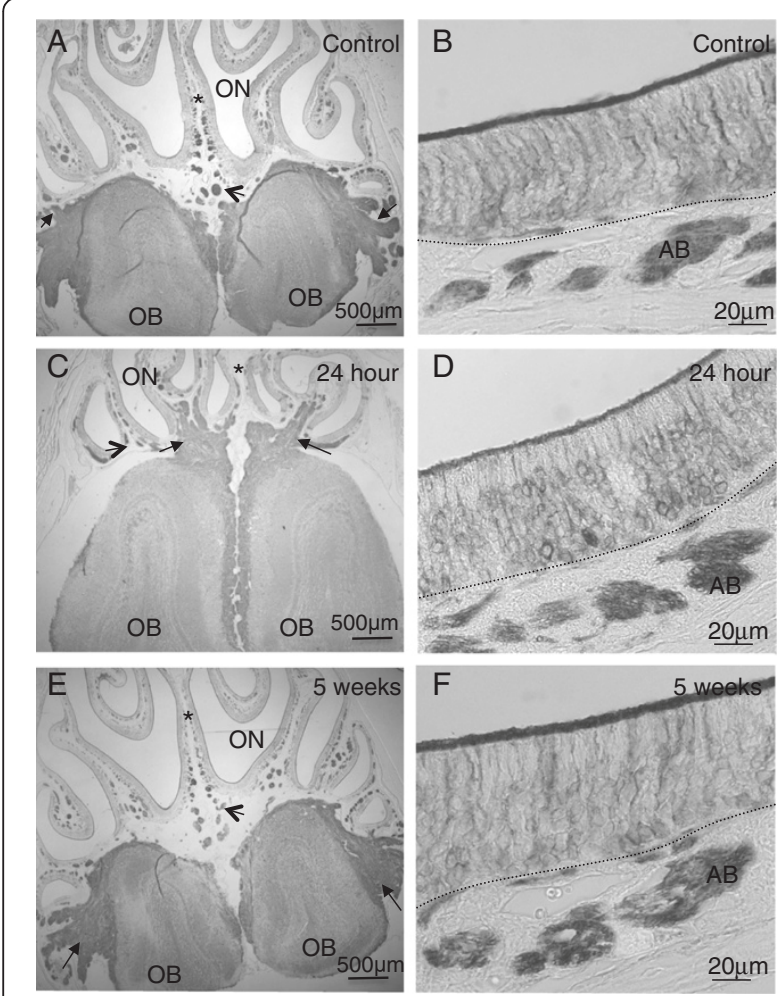

Figure 2 Morphology of $\mathrm{ON}$ and $\mathrm{OB}$ following $\mathrm{X}$-ray irradiation.

$\mathbf{A}, \mathbf{C}, \mathbf{E}$, Photomicrographs of olfactory turbinates (including the $O B$ and $\mathrm{ON}$ ) labelled with the BlllTubulin monoclonal antibody. A, In the control animals at low magnification, the axon bundles were labelled positively with BllITubulin (open arrow) and positively labelled nerve fibres were seen surrounding the olfactory bulbs (black arrows). C, 24 hours post-irradiation axon bundles remained BlIITubulin-positive (open arrow) and BlIITubulin-positive nerve fibres (black arrows) were seen linking the ON with the OB which is the same as at 5 weeks post-irradiation (E). B,D,F, Photomicrographs of the $\mathrm{ON}$ at higher magnification labelled with BllITubulin. $\mathbf{B}$, The cell soma of OSNs, their processes, cilia and axon bundles were BlllTubulin-positive in the control mice. D,F, 24 hours and 5 weeks post-irradiation the distribution of $\beta$ IIITubulin was the same as in the control mice. The dashed line in $\mathbf{B}, \mathbf{D}, \mathbf{F}$ represents the basal lamina. $A B$, axon bundle. ( $n=3$ mice per group). ${ }^{*}$ indicates septum.

BIIITubulin-positive nerve fibres can be seen traversing from the $\mathrm{ON}$ to the $\mathrm{OB}$ in the control as well as the 24 hour and 5 week groups (Figure 2A,C,E). Higher magnification of the immunohistochemical analysis of BIITTubulin in the OB can be seen in Additional file 1. Qualitative analysis reveals there was no differential localization in controls or irradiated mice. BIIITubulin labels the cell soma of glomerular and mitral cells as well as the nerve fibres in the untreated and treated mice.

We quantified the number of OSNs positively stained for BIIITubulin (immature and some mature OSNs) [28], carnosine (immature and mature OSNs) $[10,11,29]$ and olfactory marker protein (OMP) (mature OSNs) $[30,31]$ for all groups. The results showed no significant difference for BIIITubulin (Figure 3E,F), but there is an increase in the number of both carnosine- and OMPpositive OSNs at 1 week (Figure 3A-D) in the regions examined. Carnosine and OMP label more mature OSNs compared to BIIITubulin which labels only a subpopulation of mature OSNs [28].

\section{Proliferation was abolished immediately following irradiation}

For analysis of cell proliferation, three different markers were analyzed: detection of BrdU incorporation during the $S$ phase of the cell cycle (Figure 4A,D,E); Ki67, a marker of cell proliferation at G1, S and G2 phases of the cell cycle (Figure 4B,F-H) and pH3, a marker of mitosis (Figure 4C,I,J). BrdU staining showed a significant reduction in the number of proliferating cells at the level of the basal cell layer, which decreased at 2 hours and was almost abolished at 24 hours. The number of BrdU-positive cells returned to half the control level after 1 week and remained so up to 5 weeks (Figure 4A). There was a small proportion of BrdU-positive cells within the sustentacular cell layer, which disappeared at 24 hours (Figure 4A). BrdU and keratin, a marker for horizontal basal cells, did not generally co-localize, with most of the BrdU-positive cells appearing on top of keratin-positive cells in the globose basal cell layer (Figure 4D). Still, we did observe some cells positive for both BrdU and keratin at 1 week, indicating that a small percentage of proliferating cells were indeed horizontal basal cells at least at 1 week postirradiation (results not shown).

We found an increase in Ki67-positive cells in the basal layer of the $\mathrm{ON}$ at 2 hours, which was significantly reduced below normal levels after 24 hours (Figure 4B). Figure 4G,H shows a sustentacular cell and a horizontal basal cell labeled with Ki67, respectively. Overall there were more Ki67-positive cells in the sustentacular cell (apical) layer (Figure 4B).

In order to more clearly dissect cell proliferation within the $\mathrm{ON}$, we have analyzed also $\mathrm{pH} 3$, a specific marker for mitosis. Results are in agreement with BrdU, in that we have found mitosis at the level of the basal lamina, showing a reduction at 2 hours and 24 hours, with values returning almost to normal after 1 week (Figure 4C). Positive cells were seen also at the sustentacular cell layer at 1, 2 and 5 weeks (Figure 4C,I), indicating an increase in mitosis in both the basal and apical layers following irradiation. There were also a few pH3positive cells within the lamina propria at 2 weeks (Figure 4J).

The overall analysis of proliferation markers shows a significant reduction in olfactory progenitor cell proliferation following X-ray irradiation, which is almost abolished after 24 hours, and returning to normal levels after 5 weeks. 

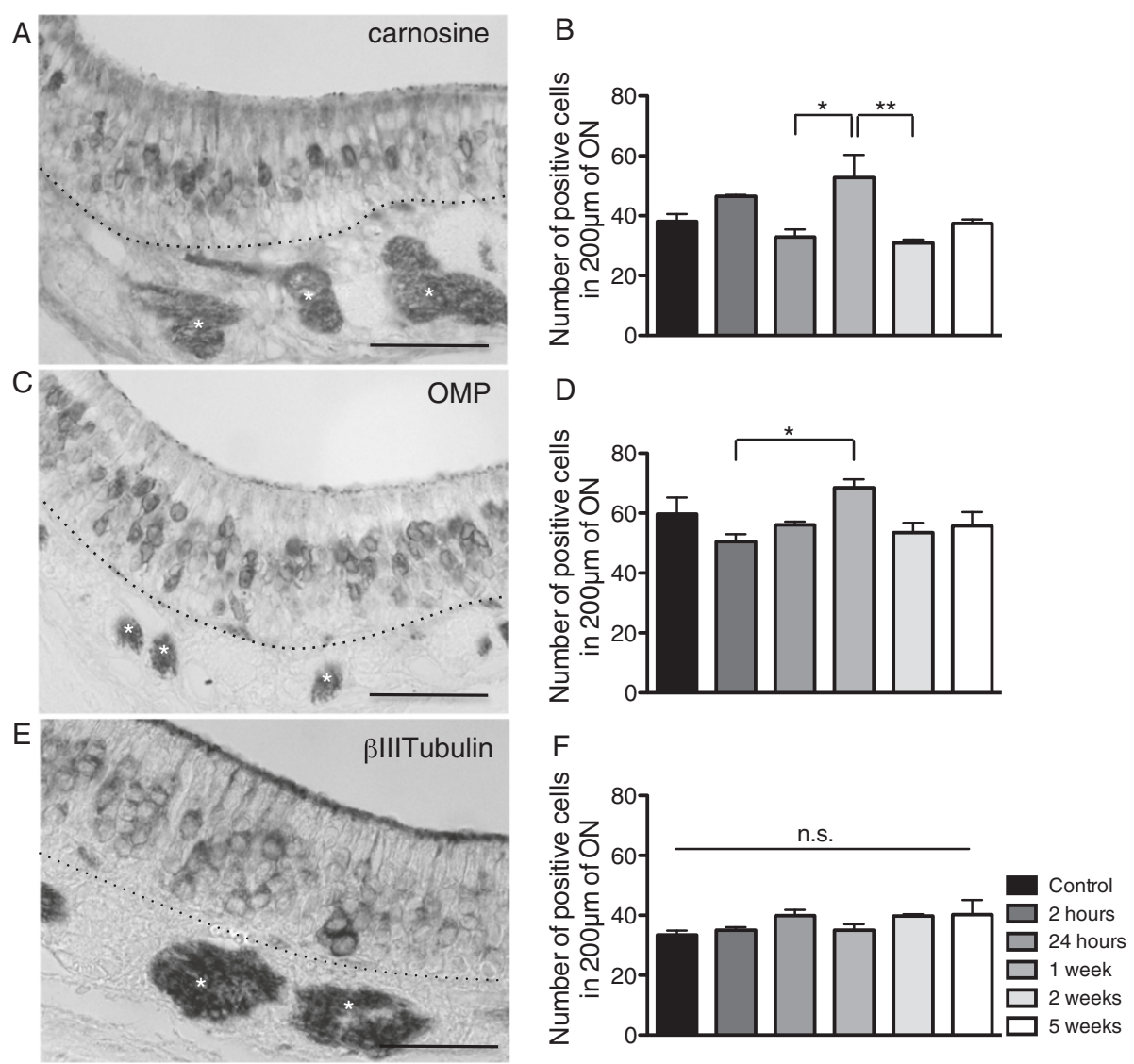

Figure 3 Analysis of olfactory neurons in the $\mathrm{ON}$ at different time points post X-ray irradiation. $A, B$, localisation and quantification of carnosine-positive neurons ( $\mathrm{n}=3$ mice); $\mathbf{C}, \mathbf{D}$, OMP-positive neurons ( $\mathrm{n}=3$ mice) and $\mathbf{E}, \mathbf{F}, \beta$ IIITubulin-positive neurons ( $\mathrm{n}=3$ mice). (Carnosine: $\left.F_{(5,12)}=5.765, p=0.0061 ; O M P: F_{(5,12)}=3.079, p=0.0513\right) .{ }^{*} p \leq 0.05,{ }^{* *} p \leq 0.01$, n.s. not significant. $\mathbf{A}$, carnosine, $\mathbf{C}$, OMP and $\mathbf{E}$, $\beta$ IIITubulin labelling in the naive control group. (* white) Axon bundle. Dashed line indicates basal lamina. Scale bars $=50 \mu \mathrm{m}$.

\section{X-ray irradiation did not induce apoptosis in the ON}

Apoptotic cells were quantified by terminal deoxynucleotidyl transferase mediated dUTP nick end labeling (TUNEL), which measured fragmented DNA by incorporating fluorescein-12-dUTP at 3'-OH DNA ends, using the terminal deoxynucleotidyl transferase enzyme. Apoptotic cells were quantified separately at the level of the basal, intermediate and sustentacular cell layers and we saw a significantly higher number of apoptotic cells within the basal and intermediate cell layers of the $\mathrm{ON}$ (Figure 5A,C). This distribution was roughly the same for irradiated and non-irradiated groups. When the total number of apoptotic nuclei throughout the $\mathrm{ON}$ was quantified, we did not observe an increase in apoptosis. Instead, we observed a significant decrease in apoptosis 2 hours post-irradiation (Figure 5B).

\section{Anatomical morphology of the basal lamina post- irradiation}

We noticed a significant disruption of the basal lamina starting 1 week post-irradiation, as seen by keratin- positive horizontal basal cells that line the basal lamina (Figure 6B,C), compared to the controls (Figure 6A). These areas did not present an increase in BrdU incorporation, showing there was no increase in proliferation where the basal lamina was disrupted (results not shown). When analyzing the position of the OSNs as indicated by BIIITubulin staining the basal lamina was not disrupted at 24 hours but was disrupted at 5 weeks where OSNs can be seen below the basal lamina in a pouch-like configuration within the lamina propria where BIIITubulin-positive axon bundles (red) and GFAP-positive ensheathing cells (green) are evident (Figure 6D).

\section{Migration of glandular cells post-irradiation}

CD15 labels duct cells of the Bowman's gland in the ON and acinus cells in the lamina propria (Figure 6E-H). Importantly, CD15 expression was seen apically in the mucous layer of the ON (Figure 6E). At 24 hours CD15 expression was absent from the mucosal layer (Figure 6F), faint at 1 week (Figure 6G) and returning to 

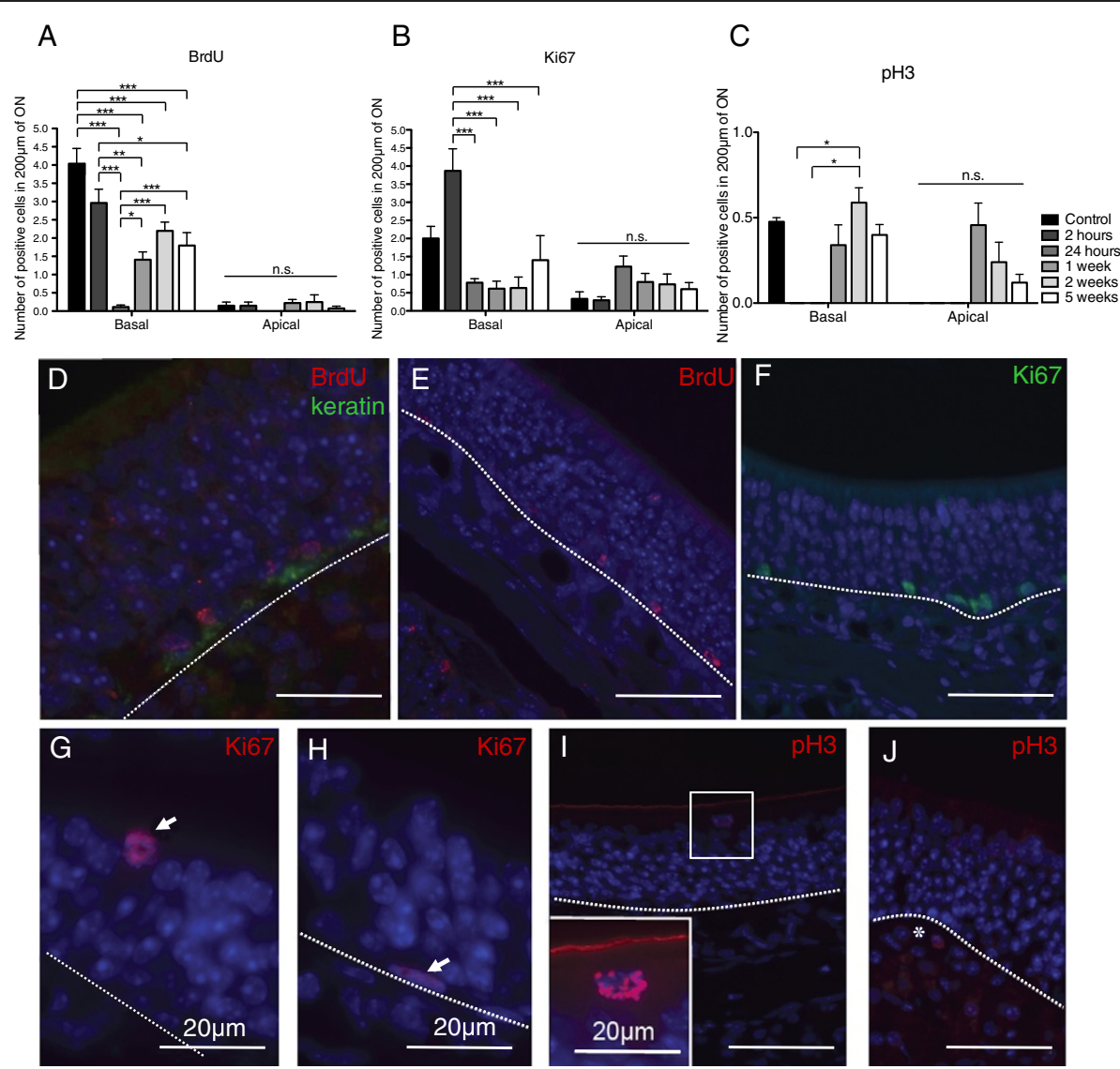

Figure 4 Analysis of cell cycle markers in the mouse $\mathbf{O N}$ following $\mathbf{X}$-ray irradiation. $\mathbf{A}, \mathbf{B}, \mathbf{C}$, Proliferation in the $\mathrm{ON}$ for different time points following X-ray irradiation, as quantified by $\mathbf{A}$, BrdU incorporation $\left(F_{(11,78)}=28.02, p \leq 0.0001, n=3\right.$ mice); $\mathbf{B}$, Ki67 expression $\left(F_{(11,40)}=7.622\right.$, $p \leq 0.0001, n=3$ mice); $\mathbf{C}, p H 3$ expression $\left(F_{(11,40)}=4.369, p=0.0003, n=3\right.$ mice). ${ }^{*} p \leq 0.05,{ }^{* *} p \leq 0.01,{ }^{* * *} p \leq 0.001$, n.s. not significant. $\mathbf{D}, \mathbf{E}$, BrdU was mainly observed on cells lying on top of the basal lamina (keratin). Ki67 expression at 2 hours in the basal lamina (F), in the sustentacular cell layer at 1 week (arrow) $(\mathbf{G})$ and a horizontal basal cell positive for Ki67 at 2 weeks (arrow) (H), pH3 expression in the sustentacular cell layer at 5 weeks $(\mathbf{I})$ and in the lamina propria at 2 weeks $(\boldsymbol{J}$ *). Dashed lines indicate basal lamina. All sections have nuclei counterstained with DAPI (blue). Scale bars: D-F,IJ, 50 um.

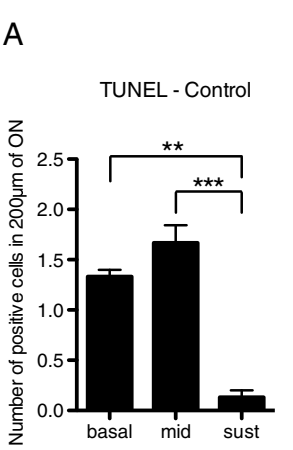

B
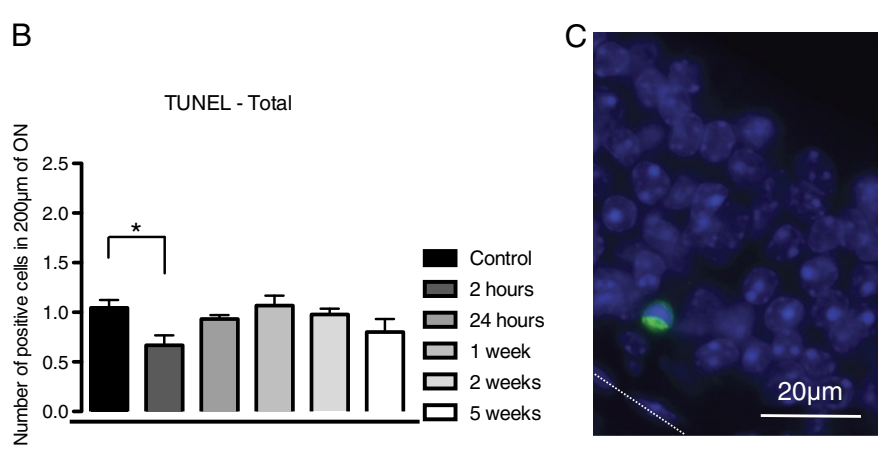

Figure $\mathbf{5}$ Analysis of apoptosis in the mouse ON following X-ray irradiation. A, Quantification of apoptotic cell nuclei in the ON of control naive animals in the basal cell layer, intermediate cell layers and sustentacular cell layer $\left(F_{(17,36)}=8.804, p \leq 0.0001, n=3\right.$ mice). B, Total number of apoptotic cell nuclei throughout the ON for each group $\left(F_{(5,12)}=2.862, p=0.0629, n=3\right.$ mice). C, TUNEL labeling (green), DAPI (blue), 2 weeks post X-ray irradiation. Dashed line indicates basal lamina. ${ }^{*} p \leq 0.05,{ }^{* *} p \leq 0.01,{ }^{* * *} p \leq 0.001$. 

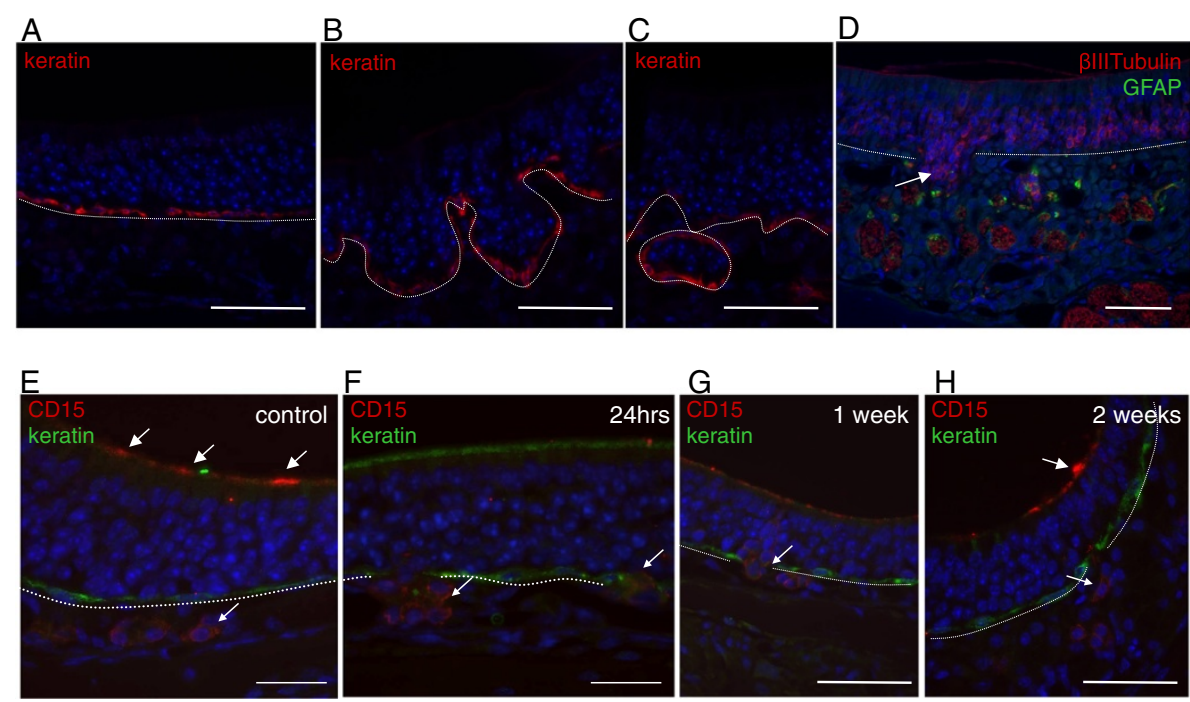

Figure 6 Anatomical analysis of the mouse ON following X-ray irradiation. A-C, keratin staining showing A, intact basal lamina in control mice and $\mathbf{B}, \mathbf{C}$, disrupted basal lamina at 1 week post X-ray irradiation. Keratin (red), DAPI (blue). E-H, CD15 staining post X-ray irradiation of the $\mathrm{ON}$. E, in control mice keratin (green) labeled horizontal basal cells and CD15 (red) labeled glandular cells in the lamina propria (small arrow) as well as the apical mucous layer (white arrows). F, 24 hours post-irradiation CD15-positive glandular cells (small arrows) were seen in the lamina propria but no longer in the apical mucous layer. G, 1 week post-irradiation CD15-positive glandular cells were seen traversing the basal lamina (small arrow). H, 2 weeks following irradiation CD15 labeling returned to the apical mucous layer (white arrow) and CD15-positive cells remained in the lamina propria (small arrow). D, BllITubulin-positive olfactory neurons were seen in a disruption of the basal lamina 5 weeks post X-ray irradiation (white arrow). GFAP-positive olfactory ensheathing glia were seen surrounding axon bundles. BlIITubulin (red), GFAP (green), DAPI (blue). Dashed line indicates basal lamina. Scale bars: A-H, 50 m.

normal levels 2 weeks following irradiation (Figure $6 \mathrm{H}$ ). This result indicates involvement of Bowman's glands following irradiation.

Moreover we saw many CD15-positive cells in between the lamina propria and the $\mathrm{ON}$ where they do not normally appear (Figure 6F,G). Not all areas where the basal lamina was disrupted had CD15-positive cells and not all the cells in a single disrupted region were CD15positive.

\section{Expression of neuronal transcription factors post- irradiation}

We observed a statistically significant increase in both Mash1 (Figure 7A) and Pax6 (Figure 7B) expression in the mouse $\mathrm{ON}$ following irradiation, with a peak at 24 hours. Mash1 expression was seen in the nuclei of sustentacular cells and OSNs throughout the ON (Figure 7C,E,G). Pax6 nuclear expression was seen throughout the $\mathrm{ON}$ in the basal layer as well as the neuronal layer and the sustentacular cell layer (Figure 7D,F,H). The areas of the ON where Pax6 expression patterns were effected by irradiation was most evident in the bowl-like areas (Figure 1B, 7D, F, H). At 24 hours post-irradiation where there was an increase in expression of Mash1 and Pax6 (Figure 7A,B) with more nuclear staining evident in cells within the sustentacular cell layer of the $\mathrm{ON}$ at this time point (Figure 7E,F). Quantification of numbers of cells labeled with Mash1 and Pax6 was represented as the total number cells in the $\mathrm{ON}$ and not separately into specific cell types.

\section{X-ray irradiation of the nose disrupts olfactory function}

To assess the olfactory function following X-ray irradiation of the mouse nose, two olfactory tests were performed: the Buried Food Pellet and the Habituation/ Dishabituation test at 24 hours, 1 week, 2 weeks and 5 weeks (five animals were anlysed per group). The Buried Food Pellet measures the mouse's ability to find a buried piece of food using olfactory cues. The Habituation/Dishabituation test assesses the mouse's ability to discriminate between different odours. A decrement in the amount of time the mouse spends with its nose to the odour is inferred to signal its ability to habituate to a repeatedly exposed odour. The increase in time exploring a new odour is interpreted to reflect dishabituation. Irradiated mice had no detectable change in behaviour with respect to controls either during their time in the home cage or during behavioural testing.

Results for the Buried Food Pellet test (Figure 8A) show a statistically significant difference between groups, as determined by One-way ANOVA. In particular, mice spent significantly more time to find the buried food pellet 24 hours post-irradiation, with respect to control group ( $\mathrm{p} \leq 0.05)$, indicating an impairment in the 


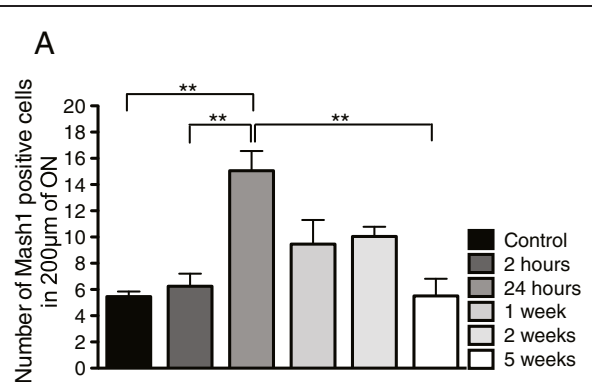

C

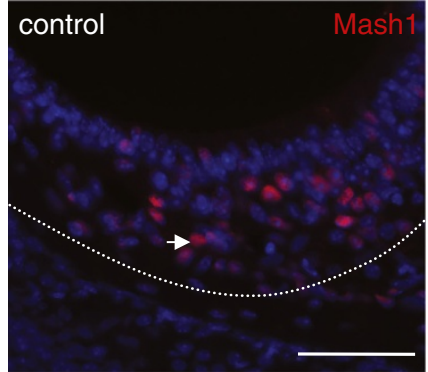

E

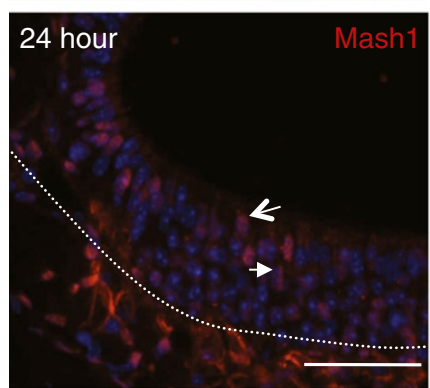

$\mathrm{G}$

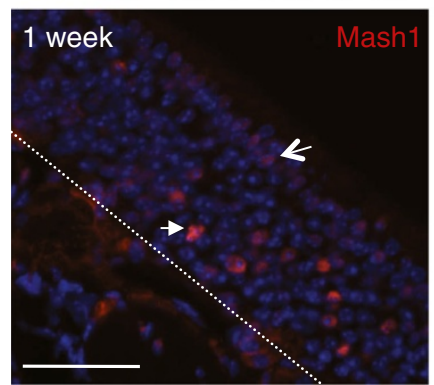

B

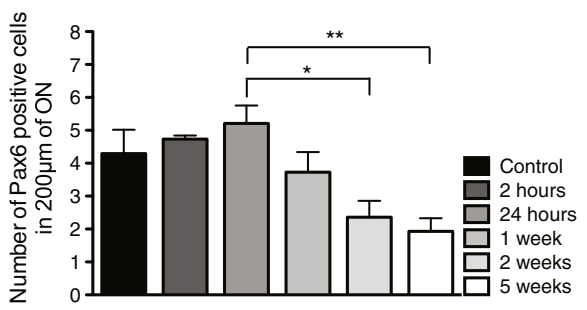

D

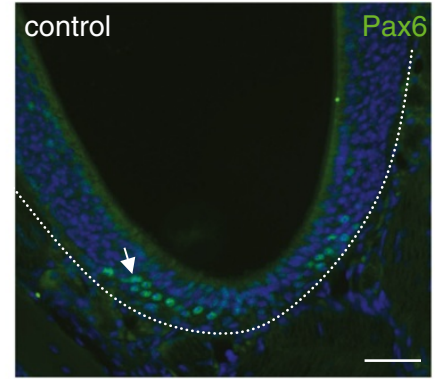

$\mathrm{F}$

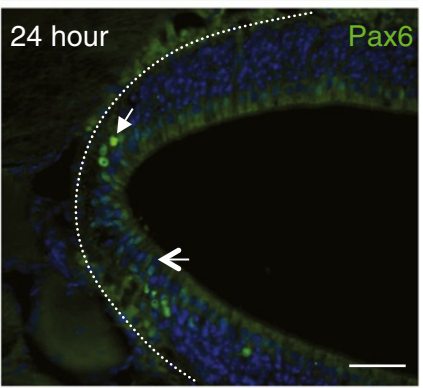

$\mathrm{H}$

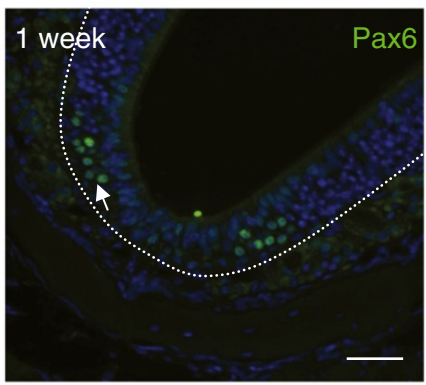

Figure 7 Analysis of the transcription factors Mash1 and Pax6 following X-ray irradiation. The quantification of Mash1 (A) ( $\mathrm{n}=5$ mice) and Pax6 (B) ( $n=5$ mice) expression in the ON, for different time points post $X$-ray irradiation, showed a peak at 24 hours for both transcription factors (Mash1: $\mathrm{F}_{(5,12)}=9.239, \mathrm{p}=0.0008 ;$ Pax6: $\mathrm{F}_{(5,16)}=4.9991, \mathrm{p}=0.0061$ ). Mash1 staining in $\mathbf{C}$, control, $\mathbf{E}, 24$ hours and $\mathbf{G}, 1$ week post $\mathbf{X}$-ray irradiation. There was nuclear expression of Mash1 in OSNs (white arrows) and sustentacular cells (open arrow). Pax6 staining in $\mathbf{D}$, control, $\mathbf{F}, 24$ hours and $\mathbf{H}, 1$ week post X-ray irradiation. Pax6 localisation appeared in the nuclei of OSNs (white arrows) in controls (D), and 24 hours (F) and 1 week (H) post-irradiation. In particular, 24 hours post-irradiation, Pax6-positive nuclei appeared in the sustentacular cell layer (open arrow). Most of the Pax6 immunoreactivity appeared in the bowl-like areas of the ON. Dashed line indicates basal lamina. All sections have nuclei counterstained with DAPI (blue). Scale bars: C,E,G, $50 \mu \mathrm{m} ; \mathrm{D}, \mathrm{F}, \mathrm{H}, 30 \mu \mathrm{m} .{ }^{*} p \leq 0.05,{ }^{*} \mathrm{p} \leq 0.01$.

olfactory function at this time point. Moreover, there seems to be a trend to return to normal values, as seen 1,2 and 5 weeks post-irradiation.

For the Habituation/Dishabituation test, we measured two different odours: strawberry and coconut (Figure 8B). For strawberry (with respect to water), we did not see a significant difference after 24 hours but only after 1 week $(\mathrm{p} \leq 0.05)$, and this impairment was maintained up to 5 weeks. Instead, for coconut (with respect to strawberry), we saw a significant impairment in identifying this odour as new at 24 hours $(\mathrm{p} \leq 0.05)$. Moreover, this impairment recovered over time, as seen after 1,2 and 5 weeks. 

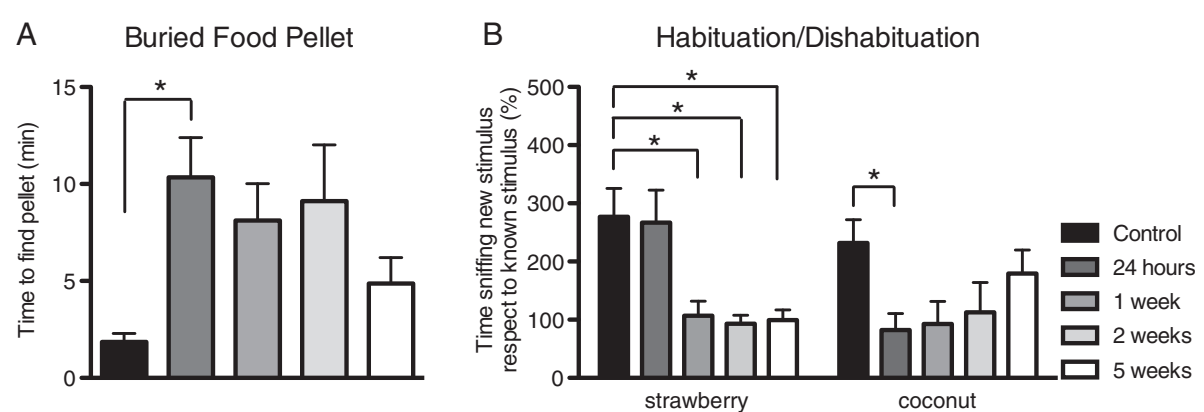

Figure 8 Behavioural analysis of irradiated mice. A, Buried Food Pellet test measures the latency to find a food pellet. A significant impairment was found 24 hours post $X$-ray irradiation $\left(F_{(4,34)}=2.754, p=0.0437, n=5\right.$ mice). B, Habituation/Dishabituation test measures the amount of time spent in investigating a new odour, strawberry and coconut. A significant impairment was found 24 hours post $X$-ray irradiation in the identification of coconut, while for strawberry this impairment is only seen after 1 week $\left(F_{(4,27)}=2.540, p=0.0629, n=5\right.$ mice; $\left(F_{(4,31)}=\right.$ 5.724, $\mathrm{p}=0.0014), \mathrm{n}=5$ mice respectively). ${ }^{*} \mathrm{p} \leq 0.05$.

Overall, performances in both tests demonstrate a significant impairment in the olfactory function following X-ray irradiation of the nose.

\section{Discussion}

Following X-ray irradiation, we observed an overall decrease in cell proliferation at 24 hours, a complete abolition of mitosis at 2 and 24 hours and a decrease in apoptosis at 2 hours. These data seem to indicate that the $\mathrm{ON}$, and especially the active cycling zone of the $\mathrm{ON}$, the basal lamina, has suffered a cell cycle arrest immediately after and as a consequence of ionizing radiation. X-ray irradiation has been shown before to induce permanent cell cycle arrest and the exhibition of senescence-like phenotypes in normal human cells [32] and to induce senescence in adult human mesenchymal stem cells [33]. We do not believe these cells have entered senescence, a process in which cells permanently stop dividing and that can happen after DNA damage following X-ray irradiation, because both proliferation and apoptosis tend to return to normal levels after $2-5$ weeks. We believe these cells have entered a reversible cell cycle arrest triggered by ionizing radiation-induced DNA damage, from which they recover after only 1-2 weeks, confirming the plasticity of the ON. Following X-ray irradiation, there are variations in radiation sensitivity of neural stem and progenitor populations in the developing mouse brain [34,35]. This radiation sensitivity applies to cell proliferation and apoptosis. X-ray irradiation of the adult mouse nose did not cause increased cell death at any time points post-irradiation. 8 Gy of X-rays (used in this study) caused a significant increase in the numbers of apoptotic nuclei in the dentate subgranular zone following X-ray exposure to the brains of mice [36]. A single 1 Gy dose of irradiation caused an increase in apoptosis within the subventricular zone however, no apoptosis was observed in other brain regions [37]. Therefore different regions of the mouse central nervous system have varying levels of sensitivity to irradiation with respect to both the proliferation of neural precursors as well as cell death.

Contrary to other models of ON degeneration, which result in high morphological alterations and overall degeneration of the ON, our model seems to target specifically the proliferating cell populations, with minor morphological changes. We have found a disruption of the basal lamina at 1 and 2 weeks post-irradiation, but the overall gross morphology of the ON remained unaltered.

As expected, for all groups, the changes in proliferation and apoptosis mostly occurred in the basal lamina, indicating that this area is indeed actively cycling. This area is historically considered the locus for olfactory stem cells in the $\mathrm{ON}$ and the only zone for cell proliferation. Our results have also shown that apical sustentacular cells undergo proliferation and apoptosis. Following X-ray irradiation, there are greater numbers of cells in the apical layer of the ON expressing Ki67 compared to BrdU. It has been shown before that nestin, an intermediate filament protein expressed in progenitor cells of the neural lineage, in the ON is mainly expressed by endfeet and inferior processes of sustentacular cells [10]. It has also been shown that during mouse ON development, in particular at E12.5, there are two populations of dividing progenitors, located respectively on the apical and basal sides of the ON [38]. The proportion of basal progenitors then increases progressively, as development of the $\mathrm{ON}$ proceeds, and that of apical progenitors decreases $[39,40]$. It has been suggested that these apical progenitors, which express Mash1, would give rise to more mature progenitors that migrate basally [38]. Others have shown that apical progenitors also express the transcription factors Six1 and Hes1 [41] and that they may be progenitors for sustentacular cells. It could be that different genes regulate neurogenesis differently during embryonic and established neurogenesis $[37,42,43]$. The endfoot of the sustentacular 
cell is adjacent to the basal lamina of the ON. We have shown that the basal lamina is disrupted following X-ray irradiation. It is possible that this process causes the sustentacular cell to undergo morphological changes. A study of the human ON showed that nestin expression in sustentacular cells was related to olfactory function however, olfactory impairment was not connected with abnormalities at the basal cell level [44]. Overall, it seems that there might be indeed a role for sustentacular cells that is more complex that presently believed.

CD15-positive olfactory glandular cells migrate from the lamina propria into the basal layer of the ON corresponding to a severe disruption in the basal lamina at 1 and 2 weeks post-X-ray irradiation. A previous study showed that degeneration of the $\mathrm{ON}$ during normal aging spatially co-localizes with lesions in the Bowman's gland in the mouse olfactory mucosa [45]. We have observed activation/migration of CD15-positive glandular cells coinciding with an increase in olfactory neuron markers (carnosine and OMP), an increase in cell proliferation and an overall surge of activation/regeneration in the ON. CD15 is considered a marker for glandular cells but it has been shown previously to label adult neural stem cells [46,47]. The previous demonstration that olfactory cell populations marked by CD15 give rise to neurospheres [11], indicates that glandular cells marked by CD15 might have neurogenic potential. It has been proposed that there is a mesenchymal stem cell population in the lamina propria, which is able to cross to the ON $[48,49]$. The disruption of the basal lamina and the opportunity for CD15-positive glandular cell to migrate across the basal lamina as a consequence of X-ray irradiation, leads us to hypothesize that there may be a fluidic interaction between Bowman's gland in the lamina propria and the $\mathrm{ON}$.

Mash1 is a transcription factor involved in neurogenic cell fate [50-52], and is necessary for the differentiation of OSNs in the ON [42]. Pax6 is a transcription factor expressed in embryonic and adult stem cells and involved in determination of neurogenic cell fate [53,54]. In the olfactory system Pax6 has been shown to be involved in the development of olfactory supporting cells [55]. Both Mash1 and Pax6 were expressed in cells throughout the ON (including sustentacular cells in the apical layer). The numbers of Pax6- and Mash1-positive nuclei are at their highest levels 24 hours post-irradiation and then decline from 1-5 weeks post-irradiation. This increase in transcription factors subsequently led to a greater number of mature OSNs 1 week post-irradiation. We know from previous experiments that an increase in the numbers of Mash1-positive cells followed a reduction in OSNs after bulbectomy [56]. Following methyl bromide lesion, expression of the transcription factor p63 is no longer evident in horizontal basal cells [9].
It is re-expressed 3 days post-lesion and by 7 days postlesion, ORNs are evident [9]. However, another cue for regulating transcription factors is driven by the apoptosis of olfactory precursors. Over expression of the apoptosis signaling regulating kinase-1 (ASK1) in adult hippocampus-derived progenitor cells activated the Mash1 promoter [57].

X-ray irradiation has undoubtedly resulted in impairment in the olfactory function, measured by both the Buried Food Pellet test and the Habituation/Dishabituation test. It is evident at 24 hours post-irradiation that there is olfactory impairment. As olfactory bulbs were protected by a lead shield during irradiation, we do not think the olfactory impairment is due to a deficit in olfactory bulb function, OSN signaling via axons or odorant detection by olfactory neuron cilia. The examination of $\beta$ IIITubulin expression in the cell soma, nerve fibres and cilia of OSNs in the ON and the nerve fibres, glomerular and mitral cells of the bulbs showed no change following irradiation. Previous studies have shown that $\beta$ IIITubulin forms microtubules that form neurites [58] and that it is specific for the cilia, dendrites, somata and axons of OSNs $[59,60]$. Following axonal degeneration caused by bulbectomy in the rat, $\beta$ IIITubulin expression is lost in OSNs [59]. This did not occur in our irradiated mice. In the Habituation/Dishabituation test one of the odours (strawberry) could still be identified after 24 hours and impairment for this odour was only seen 1 week post-irradiation. The repertoire of OSNs in the mouse ON is highly complex $[61,62]$, so that the identification of each odour probably relies on the use of distinct or partially distinct OSN families, differently affected by our irradiation protocol. The Buried Food Pellet test relies on the animal's natural tendency to use olfactory cues for foraging whereas the Habituation/ Dishabituation test relies on the animal's tendency to investigate novel smells and discriminate between different odours. The irradiation of the $\mathrm{ON}$ led to an immediate disruption of olfactory responses. Detection of general odorants by the vomeronasal organ has been reported $[63,64]$. Examination of the vomeronasal organs of the irradiated mice compared to the control group showed no histological aberrations. Therefore we do not attribute the loss of olfactory function to a defect in the vomeronasal organs of irradiated mice. However, we were able to show that the mucous layer as shown by CD15 expression was absent at 24 hours post-irradiation. Nagashima \& Touhara [65] demonstrated that enzyme inhibitors in the mucosa cause the enzymatic conversion of odours fast enough to affect recognition of the odorant at the levels of the OSNs. Therefore, following X-ray irradiation the detection and discrimination of odours is affected by the differential presence of nasal mucous. 


\section{Conclusions}

This study has demonstrated that X-ray irradiation of the $\mathrm{ON}$ induces a reversible cell cycle arrest in the $\mathrm{ON}$ as well as a series of transcriptional alterations and a disruption of olfactory function which are mostly recovered 5 weeks post-irradiation. Coincident with changes to the basal lamina and basally situated olfactory stem cell populations, the sustentacular and glandular cells of the ON were shown for the first time to respond to irradiation by undergoing anatomical and spatial alterations. This study extends the understanding of ON plasticity and chemosensory function to include the role of olfactory supporting cells. Moreover, it might impact on the understanding of the effects on proliferating cells of ionizing radiation, which is commonly used in computed tomography scans, cancer radiotherapy and nuclear medicine.

\section{Methods}

\section{Animals}

All experiments were carried out using wild-type male C57BL/6 J mice at 8 weeks of age and have been approved by the Garvan Institute of Medical Research/St Vincent's Hospital Animal Ethics Committee and conducted in accordance with the Australian code of practice for the care and use of animals for scientific purposes ( $7^{\text {th }}$ edition, 2004). Animals were kept in a 12-hour light/dark cycle, with food and water ad libitum and handled for 1 week before experimentation in order to diminish their stress or anxiety.

\section{X-ray irradiation}

Mice were anaesthetized with an intraperitoneal injection of $75 \mathrm{mg} / \mathrm{Kg}$ Ketamine plus $15 \mathrm{mg} / \mathrm{Kg}$ Xylazine and placed in a circular Perspex pie chamber with 12 compartments. This was covered with a lead shield designed to protect the whole body except the nose snout (external diameter $21.5 \mathrm{~cm}$, hole diameter $6 \mathrm{~cm}$; Figure 1A). Care was taken to protect the olfactory bulbs. Mice were irradiated in groups of 5 with 8 Gy of X-rays, administered in a single dose at a rate of $0.9 \mathrm{~Gy} / \mathrm{min}$. X-ray irradiation was carried out in a X-RAD 320 X-ray irradiator (Precision X-Ray Inc.). Mice were randomly assigned to one of 5 groups with survival times of 2 hours ( $\mathrm{n}=3$ mice), 24 hours ( $\mathrm{n}=8$ mice), 1 week $(\mathrm{n}=8$ mice), 2 weeks ( $\mathrm{n}=8$ mice) or 5 weeks $(\mathrm{n}=8$ mice), with daily monitoring and weighing for the duration of the experiment. The control group was not irradiated and consisted of paired littermates.

\section{BrdU injection}

The thymidine analogue 5-bromo-2'deoxyuridine (BrdU, Sigma) was diluted to $10 \mathrm{mg} / \mathrm{ml}$ in $0.9 \%$ saline solution and an intraperitoneal injection was administered at a dose of $50 \mathrm{mg} / \mathrm{Kg}$ body weight, 2 hours before transcardiac perfusion.

\section{Transcardiac perfusion and tissue processing}

Mice were anaesthetized with an intraperitoneal injection of $100 \mathrm{mg} / \mathrm{Kg}$ Ketamine plus $20 \mathrm{mg} / \mathrm{Kg}$ Xylazine and perfused with heparinized saline $(10 \mathrm{IU} / \mathrm{ml})$ followed by $4 \%$ paraformaldehyde (PFA, Proscitech). Olfactory tissue was dissected together with the olfactory bulbs and post-fixed in 4\% PFA overnight. The ON was decalcified for 7 days in 15\% EDTA/4\% PFA and processed for paraffin embedding. Coronal serial sections of $6 \mu \mathrm{m}$ were collected via a microtome (Leica). Tissue sections were left at $60^{\circ} \mathrm{C}$ for 1 hour for melting of the paraffin, dewaxed in Histoclear solution (National Diagnostics) and rehydrated through a graded series of alcohol.

\section{Hematoxylin and eosin staining}

H\&E staining was performed for each animal, at intervals of $180 \mu \mathrm{m}$ for the entire length of the mouse nose (including the $\mathrm{OB}$ and the vomeronasal organ), in order to determine the same coronal level for all animals analyzed. Sections were stained with hematoxylin for $45 \mathrm{sec}-$ onds and washed in tap water and then stained with eosin for 30 seconds and washed in tap water. Tissue was dehydrated in a graded series of alcohols and slides mounted with Eukitt (Sigma).

\section{Immunohistochemistry}

For immunohistochemical analysis against olfactory marker protein (OMP) and carnosine, antigen retrieval was performed by immersing slides in TE $1 \mathrm{X} \mathrm{pH} 9.0$ at high temperature. Non-specific staining was blocked in $10 \%$ goat and rabbit serum (Sigma) plus 1\% bovine serum albumin for $1 \mathrm{~h}$. Sections of $\mathrm{ON}$ and $\mathrm{OB}$ from control and irradiated mice were incubated with the primary antibody anti- $\beta$ IIITubulin. The ON further examined using antiOMP, anti-carnosine and (Table 1 ) overnight at $4^{\circ} \mathrm{C}$. Control sections were incubated with $1 \%$ bovine serum albumin and processed in parallel. Endogenous peroxidase activity was quenched in $0.3 \% \mathrm{H}_{2} \mathrm{O}_{2}$ in PBS for $15 \mathrm{~min}$. Sections were incubated with the respective biotinylated goat anti-rabbit, horse anti-mouse or rabbit anti-goat secondary antibodies (1:300, Vector Laboratories) for $30 \mathrm{~min}$ utes at room temperature. Avidin-Horseradish Peroxidase complex was prepared using the Vector $\mathrm{ABC}$ Elite kit (Vector Laboratories) according to the manufacturer's recommendations. Immunoreactivity was visualised using $\mathrm{DAB}$ as the chromogen and slides mounted using Aquamount (BDH, VWR).

\section{Immunofluorescence analysis}

A list of all primary antibodies used for immunofluorescence experiments can be found in Table 1. Antigen 
Table 1 List of primary antibodies used for immunofluorescence and immunohistochemical analysis

\begin{tabular}{|c|c|c|c|c|c|c|}
\hline Antibodies & Cell type & Origin & Company & Dilution & $\begin{array}{l}\text { Antibody } \\
\text { pre-treatment }\end{array}$ & Abbreviation \\
\hline anti-ASH1 (MASH1) & neurogenic precursors & rabbit polyclonal & Millipore & $1: 20$ & Citrate buffer & Mash1 \\
\hline anti-bromodeoxyuridine & proliferative cells & $\begin{array}{l}\text { mouse } \\
\text { monoclonal }\end{array}$ & Millipore & $1: 50$ & $\mathrm{HCl}$ & BrdU \\
\hline anti-carnosine & $\begin{array}{l}\text { immature and mature } \\
\text { OSNs }\end{array}$ & rabbit polyclonal & Millipore & $1: 50$ & TE buffer & carnosine \\
\hline anti-CD15 & glandular cells & $\begin{array}{l}\text { mouse } \\
\text { monoclonal }\end{array}$ & BD Biosciences & $1: 10$ & Citrate buffer & CD15 \\
\hline $\begin{array}{l}\text { anti-glial fibrillary acidic } \\
\text { protein }\end{array}$ & olfactory ensheathing glia & rabbit polyclonal & Dako & $1: 250$ & nil & GFAP \\
\hline anti-keratin & $\mathrm{HBCS}$ & rabbit polyclonal & Dako & $1: 200$ & nil & keratin \\
\hline anti-Ki-67, clone SP6 & proliferative cells & rabbit monoclonal & Thermo Scientific & $1: 50$ & nil & Ki67 \\
\hline $\begin{array}{l}\text { anti-olfactory marker } \\
\text { protein }\end{array}$ & mature OSNs & goat polyclonal & $\begin{array}{l}\text { Santa Cruz } \\
\text { Biotechnology }\end{array}$ & $1: 800$ & TE buffer & OMP \\
\hline anti-Pax6, C-terminus & neurogenic precursors & rabbit polyclonal & Millipore & $1: 200$ & Citrate buffer & Pax6 \\
\hline $\begin{array}{l}\text { anti-phospho-Histone } \mathrm{H} 3 \\
{\left[\mathrm{pSer}^{10}\right]}\end{array}$ & mitotic marker & rabbit polyclonal & Sigma & $1: 200$ & nil & $\mathrm{pH} 3$ \\
\hline anti- $\beta$ III Tubulin & $\begin{array}{l}\text { immature and mature } \\
\text { OSNs }\end{array}$ & $\begin{array}{l}\text { mouse } \\
\text { monoclonal }\end{array}$ & Promega & $1: 800$ & nil & BlITubulin \\
\hline
\end{tabular}

retrieval with citrate buffer was performed by immersing slides in $8.2 \mathrm{mM}$ tri-sodium citrate plus $1.8 \mathrm{mM}$ citric acid at high temperature. $\mathrm{HCl}$ treatment was performed by incubating sections in $2 \mathrm{M} \mathrm{HCl}$ at $60^{\circ} \mathrm{C}$ for $35 \mathrm{~min}$ utes. Blocking was performed with $10 \%$ goat serum (Sigma) and tissue permeabilization with $0.1 \%(\mathrm{v} / \mathrm{v})$ Triton X-100, except for anti-Ki67, anti-BrdU and anti$\mathrm{pH} 3$, where $0.3 \%(\mathrm{v} / \mathrm{v})$ Triton X-100 was used. Sections were incubated with the primary antibody overnight at $4^{\circ} \mathrm{C}$. Primary antibodies were probed with the secondary antibodies Alexa Fluor ${ }^{\circledR} 488$ goat anti-rabbit or goat anti-mouse (1:500, Molecular Probes, Invitrogen) or Cy3 goat anti-rabbit or goat anti-mouse (1:1000, Jackson ImmunoResearch) for 45 minutes at room temperature. Cell nuclei were stained with DAPI (Molecular Probes, Invitrogen) and slides mounted using FluorSave (Calbiochem).

For immunofluorescence double labeling, the following antibody combinations were adopted: anti-BrdU plus anti-keratin, anti-CD15 plus anti-keratin, anti-GFAP

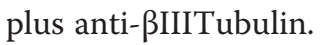

\section{TUNEL assay}

The TUNEL assay was performed by use of the DeadEnd ${ }^{\mathrm{TM}}$ Fluorometric TUNEL System (Promega), according to manufacturer's instructions. Briefly, tissue was hydrated and permeabilized by Proteinase $\mathrm{K}(20 \mu \mathrm{g} / \mathrm{ml})$ digestion for 8 minutes at room temperature. No further PFA fixation was performed. Tissue was incubated for 1 hour at $37^{\circ} \mathrm{C}$ with Terminal Deoxynucleotidyl Transferase (recombinant) and fluorescein-12-dUTP and reaction stopped by incubating slides in 2x SSC for 15 minutes. Cell nuclei counterstaining was performed by use of DAPI (Molecular Probes, Invitrogen).

\section{Imaging and quantification}

For all immunofluorescence analysis, sections were examined using an upright fluorescence microscope (Axioplan, Carl Zeiss) and pictures were acquired using a 40X and 100X oil objectives and an AxioCam digital camera (Carl Zeiss MicroImaging $\mathrm{GmbH}$ ). For all histochemical analysis, sections were examined using an upright microscope (Axiophot, Carl Zeiss MicroImaging $\mathrm{GmbH}$ ) and pictures acquired using a $2.5 \mathrm{X}$ and $40 \mathrm{X}$ dry objectives and an AxioCam digital camera (Carl Zeiss MicroImaging GmbH). No image manipulation has been performed of any kind, apart from rotation and cropping.

For each animal and marker, 5 different areas of the $\mathrm{ON}$ in the coronal section of the nose were quantified by counting the number of positively stained cells, corresponding to the middle of the nasal septum, one more superior and one more inferior area of both the left and right turbinates (Figure 1B). For all sections analyzed, these areas remained constant and were examined at the level of $100-250 \mu \mathrm{m}$ anteriorly, with respect to the end of the olfactory bulbs. For each area quantified, $200 \mu \mathrm{m}$ length of $\mathrm{ON}$ was analyzed (Figure $1 \mathrm{C}$ ). The mean number of positive cells between areas was determined for each section and these values used to determine the mean number of positive cells between animals $(n=3-5)$. 


\section{Olfactory behavioural tests}

Olfactory tests have been performed as previously described [11], with minor alterations. Mice were paired littermates to avoid possible differences caused by the animal's age. All animals performed each test only once.

\section{Buried food pellet}

This test measures the mouse's ability to find a buried food pellet using olfactory cues. Mice ( $\mathrm{n}=5$ per group) were food deprived overnight with free access to water, between $5 \mathrm{pm}$ the day prior to the test and the beginning of the test at 8 am the following day. To avoid problems associated with neophobia, mice were habituated to eat the new food by placing pieces in the home cage overnight for 3 days before the test. On the day of the test, a sultana was placed underneath the bedding material within the home cage. The floor of the cage was then completely covered with new bedding material to a depth of approximately $2.5 \mathrm{~cm}$. The latency to find the sultana and start eating was recorded using a stopwatch. A maximum cut-off time of 15 minutes was used and mice reaching the cut-off were included in the analysis as if they had found the pellet after 15 minutes.

\section{Habituation/Dishabituation}

Odorants were prepared by diluting strawberry and coconut essences (Queen Fine Foods Pty Ltd) 1:100 in distilled water. Mice were placed individually into a clean cage. Cotton buds were dipped into distilled water or odorant and are then placed through the wire cage lid and fixed with the tip at a height of $5 \mathrm{~cm}$ above the cage floor. Each stimulus was presented 3 times consecutively in the following order: water $3 x$, strawberry $3 x$, coconut $3 \mathrm{x}$, for 3 minutes each and with the mouse returning to his home cage for 1 minute between each stimulus presentation. The cumulative time spent sniffing each stimulus was measured. The behaviour sniffing is defined as orienting the nose towards the stimulus within $2 \mathrm{~cm}$ of the cotton tip or in contact with the tip. Chewing the cotton tip or contacting it with an open mouth is not counted as sniffing. The percentage of time spent sniffing the first strawberry presentation with respect to the third water was calculated. The percentage of the time spent sniffing the first coconut presentation with respect to the third strawberry was calculated.

\section{Statistical analysis}

All results were expressed as MEAN \pm SEM plotted on graph and statistical analysis was performed using GraphPad Prism software (version 5.0), with statistical significance set at $\mathrm{p} \leq 0.05$. For both olfactory tests, a one-way ANOVA was performed, followed by Dunnet's post hoc test, with respect to control group. For all immunohistochemistry analysis, a one-way ANOVA was performed, followed by Tukey's post hoc test, for comparison between all groups.

\section{Additional file}

Additional file 1: High magnification photomicrographs of $\beta$ IIITubulin labeling of the olfactory bulbs in control and irradiated mice.

\section{Abbreviations}

BrdU: 5-bromo-2'deoxyuridine; GFAP: glial fibrillary associated protein: OB: olfactory bulb; OMP: olfactory marker protein; ON: olfactory neuroepithelium; OSN: olfactory sensory neuron; PBS: phosphate buffered saline; PFA: paraformaldehyde; TUNEL: terminal deoxynucleotidyl transferase mediated UTP nick end labeling.

\section{Competing interests}

The authors declare that they have no competing interests.

\section{Authors' contributions}

CC designed the study, carried out the immunofluorescence and animal studies, performed the statistical analysis and wrote the manuscript. $\mathrm{YH}$ carried out the immunohistochemistry studies. JS participated in the design of the study. KD conceived the study, participated in its design and coordination and helped to draft the manuscript. All authors read and approved the final manuscript.

\section{Acknowledgements}

We acknowledge Dr. Tim Karl for helpful discussion about the olfactory behavioural test results and Tanya Wyatt for technical assistance in the embedding and sectioning of the paraffin embedded tissue blocks. This work was funded by grants from the Mason Foundation and Rosemary Pryor Trust. The authors indicate no potential conflict of interests.

Received: 14 August 2012 Accepted: 25 October 2012 Published: 31 October 2012

\section{References}

1. Leung $C T$, Coulombe PA, Reed RR: Contribution of olfactory neural stem cells to tissue maintenance and regeneration. Nat Neurosci 2007, 10:720-726.

2. Schwob JE: Neural regeneration and the peripheral olfactory system. Anat Rec 2002, 269:33-49.

3. Graziadei PP, Graziadei GA: Neurogenesis and neuron regeneration in the olfactory system of mammals. I. Morphological aspects of differentiation and structural organization of the olfactory sensory neurons. J Neurocytol 1979, 8:1-18.

4. Asan E, Drenckhahn D: Immunocytochemical characterization of two types of microvillar cells in rodent olfactory epithelium. Histochem Cell Biol 2005, 123:157-168.

5. Caggiano M, Kauer JS, Hunter DD: Globose basal cells are neuronal progenitors in the olfactory epithelium: a lineage analysis using a replication-incompetent retrovirus. Neuron 1994, 13:339-352.

6. Chen X, Fang H, Schwob JE: Multipotency of purified, transplanted globose basal cells in olfactory epithelium. J Comp Neurol 2004, 469:457-474.

7. Holbrook EH, Szumowski KE, Schwob JE: An immunochemical, ultrastructural, and developmental characterization of the horizontal basal cells of rat olfactory epithelium. J Comp Neurol 1995, 363:129-146.

8. Huard JM, Youngentob SL, Goldstein BJ, Luskin MB, Schwob JE: Adult olfactory epithelium contains multipotent progenitors that give rise to neurons and non-neural cells. J Comp Neurol 1998, 400:469-486.

9. Packard A, Schnittke N, Romano RA, Sinha S, Schwob JE: DeltaNp63 regulates stem cell dynamics in the mammalian olfactory epithelium. J Neurosci 2011, 31:8748-8759.

10. Doyle KL, Khan M, Cunningham AM: Expression of the intermediate filament protein nestin by sustentacular cells in mature olfactory neuroepithelium. J Comp Neurol 2001, 437:186-195. 
11. Doyle $K L$, Karl T, Hort $Y$, Duffy $L$, Shine J, Herzog $H$ : $Y 1$ receptors are critical for the proliferation of adult mouse precursor cells in the olfactory neuroepithelium. J Neurochem 2008, 105:641-652.

12. Harding JW, Getchell TV, Margolis FL: Denervation of the primary olfactory pathway in mice. V. Long-term effect of intranasal ZnSO4 irrigation on behavior, biochemistry and morphology. Brain Res 1978 140:271-285.

13. Williams SK, Gilbey T, Barnett SC: Immunohistochemical studies of the cellular changes in the peripheral olfactory system after zinc sulfate nasal irrigation. Neurochem Res 2004, 29:891-901.

14. Buron G, Hacquemand R, Pourie G, Brand G: Inhalation exposure to acetone induces selective damage on olfactory neuroepithelium in mice. Neurotoxicology 2009, 30:114-120.

15. Jacquot L, Pourie G, Buron G, Monnin J, Brand G: Effects of toluene inhalation exposure on olfactory functioning: behavioral and histological assessment. Toxicol Lett 2006, 165:57-65.

16. Bergman U, Ostergren A, Gustafson AL, Brittebo B: Differential effects of olfactory toxicants on olfactory regeneration. Arch Toxicol 2002, 76:104-112.

17. Bergstrom U, Giovanetti A, Piras E, Brittebo EB: Methimazole-induced damage in the olfactory mucosa: effects on ultrastructure and glutathione levels. Toxicol Pathol 2003, 31:379-387.

18. Buron G, Hacquemand R, Pourie G, Brand G: Carbon dioxide effects on olfactory functioning: behavioral, histological and immunohistochemical measurements. Toxicol Lett 2009, 188:251-257.

19. Schwob JE, Youngentob SL, Mezza RC: Reconstitution of the rat olfactory epithelium after methyl bromide-induced lesion. J Comp Neurol 1995, 359:15-37.

20. Schwob JE, Youngentob SL, Ring G, Iwema CL, Mezza RC: Reinnervation of the rat olfactory bulb after methyl bromide-induced lesion: timing and extent of reinnervation. J Comp Neurol 1999, 412:439-457.

21. Cowan CM, Thai J, Krajewski S, Reed JC, Nicholson DW, Kaufmann SH, Roskams AJ: Caspases 3 and 9 send a pro-apoptotic signal from synapse to cell body in olfactory receptor neurons. J Neurosci 2001, 21:7099-7109.

22. Schwob JE, Szumowski KE, Stasky AA: Olfactory sensory neurons are trophically dependent on the olfactory bulb for their prolonged survival. J Neurosci 1992, 12:3896-3919.

23. Peissner $W$, Kocher $M$, Treuer $H$, Gillardon F: lonizing radiation-induced apoptosis of proliferating stem cells in the dentate gyrus of the adult rat hippocampus. Brain Res Mol Brain Res 1999, 71:61-68.

24. Bellinzona M, Gobbel GT, Shinohara C, Fike JR: Apoptosis is induced in the subependyma of young adult rats by ionizing irradiation. Neurosci Lett 1996, 208:163-166.

25. Shinohara C, Gobbel GT, Lamborn KR, Tada E, Fike JR: Apoptosis in the subependyma of young adult rats after single and fractionated doses of X-rays. Cancer Res 1997, 57:2694-2702.

26. Tada E, Yang C, Gobbel GT, Lamborn KR, Fike JR: Long-term impairment of subependymal repopulation following damage by ionizing irradiation. Exp Neurol 1999, 160:66-77.

27. Panagiotakos G, Alshamy G, Chan B, Abrams R, Greenberg E, Saxena A, Bradbury M, Edgar M, Gutin P, Tabar V: Long-term impact of radiation on the stem cell and oligodendrocyte precursors in the brain. PLoS One 2007, 2:e588.

28. Hao S, Yu F, Yan A, Zhang Y, Han J, Jiang X: In utero and lactational lanthanum exposure induces olfactory dysfunction associated with downregulation of $\beta$ III-tubulin and olfactory marker protein in young rats. Biol Trace Elem Res 2012, 148:383-391.

29. Biffo S, Grillo M, Margolis FL: Cellular localisation of carnosine-like and anserine-like immunoreactivities in rodent and avian central nervous system. Neurosci 1990, 35:637-651.

30. Margolis FL: Olfactory marker protein (OMP). Scand J Immunol Supp/ 1982, 9:181-199.

31. Baker H, Grillo M, Margolis FL: Biochemical and immunocytochemical charaterisation of olfactory marker protein in the rodent central nervous system. J Comp Neurol 1989, 285:246-261.

32. Suzuki K, Mori I, Nakayama Y, Miyakoda M, Kodama S, Watanabe M: Radiation-induced senescence-like growth arrest requires TP53 function but not telomere shortening. Radiat Res 2001, 155:248-253.

33. Wang D, Jang DJ: Protein kinase CK2 regulates cytoskeletal reorganization during ionizing radiation-induced senescence of human mesenchymal stem cells. Cancer Res 2009, 69:8200-8207.
34. Etienne $\mathrm{O}$, Roque $\mathrm{T}$, Haton C, Boussin FD: Variation of radiation-sensitivity of neural stem and progenitor cell populations within the developing mouse brain. Int J Radiat Biol 2012, 88(10):694-702. Epub 2012 Aug 7.

35. Lazarini F, Mouthon MA, Gheusi G, de Chaumont F, Olivo-Marin JC, Lamarque S, Abrous DN, Boussin FD, Lledo PM: Cellular and behavioral effects of cranial irradiation of the subventricular zone in adult mice. PLoS One 2009, 15:e7017

36. Mizumatsu S, Monje ML, Morhardt DR, Rola R, Palmer TD, Fike JR: Extreme sensitivity of adult neurogenesis to low doses of X-irradiation. Cancer Res 2003, 63:4021-4027.

37. Amano T, Inamura T, Wu CM, Kura S, Nakamizo A, Inoha S, Miyazono M, Ikezaki K: Effects of low dose irradiation on subventricular zone cells in juvenile rat brain. Neurol Res 2002, 24:809-816.

38. Cau E, Gradwohl G, Casarosa S, Kageyama R, Guillemot F: Hes genes regulate sequential stages of neurogenesis in the olfactory epithelium. Development 2000, 127:2323-2332.

39. Cuschieri A, Bannister LH: The development of the olfactory mucosa in the mouse: electron microscopy. J Anat 1975, 119:471-498.

40. Smart $\mathrm{H}$ : Location and orientation of mitotic figures in the developing mouse olfactory epithelium. J Anat 1971, 109:243-251.

41. Ikeda K, Kageyama R, Suzuki Y, Kawakami K: Six1 is indispensable for production of functional progenitor cells during olfactory epithelial development. Int J Dev Biol 2010, 54:1453-1464.

42. Cau E, Casarosa S, Guillemot F: Mash1 and Ngn1 control distinct steps of determination and differentiation in the olfactory sensory neuron lineage. Development 2002, 129:1871-1880.

43. Beites CL, Kawauchi S, Crocker CE, Calof AL: Identification and molecular regulation of neural stem cells in the olfactory epithelium. Exp Cell Res 2005, 306:309-316.

44. Minovie A, Witt M, Prescher A, Gudziol V, Dazert S, Hatt H, Benecke H: Expression and distribution of the intermedicate filament protein nestin and other stem cell related molecules in the human olfactory epithelium. Histol Histopathol 2010, 25:177-187.

45. Kondo K, Watanabe K, Sakamoto T, Suzukawa K, Nibu K, Kaga K, Yamasoba $\mathrm{T}$ : Distribution and severity of spontaneous lesions in the neuroepithelium and Bowman's glands in mouse olfactory mucosa: agerelated progression. Cell Tissue Res 2009, 335:489-503.

46. Capela A, Temple S: LeX/ssea-1 is expressed by adult mouse CNS stem cells, identifying them as nonependymal. Neuron 2002, 35:865-875.

47. Capela A, Temple S: LeX is expressed by principle progenitor cells in the embryonic nervous system, is secreted into their environment and binds Wnt-1. Dev Biol 2006, 291:300-313.

48. Delorme B, Nivet E, Gaillard J, Haupl T, Ringe J, Deveze A, Magnan J, Sohier J, Khrestchatisky M, Roman FS, et al: The human nose harbors a niche of olfactory ectomesenchymal stem cells displaying neurogenic and osteogenic properties. Stem Cells Dev 2010, 19:853-866.

49. Tome M, Lindsay SL, Riddell JS, Barnett SC: Identification of nonepithelial multipotent cells in the embryonic olfactory mucosa. Stem Cells 2009, 27:2196-2208.

50. Guillemot F, Lo LC, Johnson JE, Auerbach A, Anderson DJ, Joyner AL: Mammalian achaete-scute homolog 1 is required for the early development of olfactory and autonomic neurons. Cell 1993, 75:463-476.

51. Kim EJ, Ables JL, Dickel LK, Eisch AJ, Johnson JE: Ascl1 (Mash1) defines cells with long-term neurogenic potential in subgranular and subventricular zones in adult mouse brain. PLoS One 2011, 6:e18472.

52. Parras CM, Galli R, Britz O, Soares S, Galichet C, Battiste J, Johnson JE, Nakafuku M, Vescovi A, Guillemot F: Mash1 specifies neurons and oligodendrocytes in the postnatal brain. EMBO J 2004, 23:4495-4505.

53. Osumi N, Shinohara H, Numayama-Tsuruta K, Maekawa M: Concise review: Pax6 transcription factor contributes to both embryonic and adult neurogenesis as a multifunctional regulator. Stem Cells 2008, 26:1663-1672.

54. Zhang X, Huang CT, Chen J, Pankratz MT, Xi J, Li J, Yang Y, Lavaute TM, Li $\mathrm{XJ}$, Ayala $\mathrm{M}$, et al: Pax6 is a human neuroectoderm cell fate determinant. Cell Stem Cell 2010, 7:90-100.

55. Davis JA, Reed R: Role of Olf- 1 and Pax- 6 transcription factors in neurodevelopment. J Neurosci 1996, 16:5082-5094.

56. Gokoffski KK, Kawauchi S, Wu HH, Santos R, Hollenbeck PLW, Lander AD, Calof AL: From Feedback Regulation of neurogenesis in the mammalian olfactory epithelium:new insights from genetics and systems biology. In The Neurobiology of Olfaction Chapter 10: Edited by Menini A Boca Raton (FL); 2010. 
57. Elmi M, Faigle R, Yang W, Matsumoto Y, Rosenqvist E, Funa K: Mechanism of MASH1 induction by ASK1 and ATRA in adult neural progenitors. Mol Cell Neurosci 2007, 36:248-259.

58. Atashi JR, Klinz SG, Ingraham CA, Matten WT, Schachner M, Maness PF: Neural cell adhesion molecules modulate tyrosine phosphorylation of tubulin in nerve growth cone membranes. Neuron 1992, 8:831-842.

59. Roskams AJ, Cai X, Ronnett GV: Expression of neuron-specific beta-III tubulin during olfactory neurogenesis in the embryonic and adult rat. Neuroscience 1998, 83:191-200.

60. Woo K, Jensen-Smith HC, Luduena RF, Hallworth R: Differential synthesis of beta-tubulin isotypes in gerbil nasal epithelia. Cell Tissue Res 2002, 309:331-335.

61. Iwema CL, Fang H, Kurtz DB, Youngentob SL, Schwob JE: Odorant receptor expression patterns are restored in lesion-recovered rat olfactory epithelium. J Neurosci 2004, 24:356-369.

62. Kondo K, Suzukawa K, Sakamoto T, Watanabe K, Kanaya K, Ushio M, Yamaguchi T, Nibu K, Kaga K, Yamasoba T: Age-related changes in cell dynamics of the postnatal mouse olfactory neuroepithelium: cell proliferation, neuronal differentiation, and cell death. J Comp Neurol 2010, 518:1962-1975.

63. Trinh K, Storm DR: Vomeronasal organ detects odorants in absence of signaling through main olfactory epithelium. Nat Neurosci 2003, 6:519-525.

64. Trinh K, Storm DR: Detection of odorants through the main olfactory epithelium and vomeronasal organ of mice. Nutrition Rev 2004, 62:S189-S192.

65. Nagashima A, Touhara K: Enzymatic conversion of odorants in nasal mucus affects olfactory glomerular activation patterns and odor perception. J Neurosci 2010, 30:16391-16398.

doi:10.1186/1471-2202-13-134

Cite this article as: Cunha et al.: Morphological and behavioural changes occur following the X-ray irradiation of the adult mouse olfactory neuroepithelium. BMC Neuroscience 2012 13:134.

\section{Submit your next manuscript to BioMed Central and take full advantage of:}

- Convenient online submission

- Thorough peer review

- No space constraints or color figure charges

- Immediate publication on acceptance

- Inclusion in PubMed, CAS, Scopus and Google Scholar

- Research which is freely available for redistribution

Submit your manuscript at www.biomedcentral.com/submit
() Biomed Central 